\title{
The enigma of herpes stromal disease
}

\author{
JAMES McGILL \\ From Southampton Eye Hospital, Wilton Avenue, Southampton SO9 4XW
}

SUMMARY Herpes stromal disease is due to direct damage as a result of viral replication, virally induced immune mechanisms, or a combination of the two. Viral replication may have a major initiating role in the production of herpes simplex and herpes zoster induced stromal disease, and steroids may initially be harmful in their treatment. On topical antiviral drugs alone, in patients who never previously had had topical steroids, 14 of 15 cases of herpes simplex induced disciform keratitis responded favourably in an average of 44 days of treatment. This compared with one out of 14 responding if steroids had previously been used, 13 of 14 requiring topical steroids and an average 112 days' treatment. In herpes zoster stromal disease cases $78 \%$ had epithelial involvement, 54 of 57 responded to topical antivirals alone without the use of steroids, $2 \%$ recurred, and treatment averaged a total of 62 days. If steroids were used alone or in combination with antivirals, there was a $50 \%$ recurrence rate and 200 day total treatment duration.

Two sorts of herpetic infections affect the corneal stroma, namely those due to herpes simplex and those due to herpes zoster infection. Both conditions present peculiar and testing diagnostic or therapeutic problems in many cases, and both conditions are often difficult to treat, prone to recurrences leading to corneal scarring, progression of disease to other parts of the eye not initially affected, and much visual loss. It is uncertain whether stromal disease is caused by viral replication alone (leading to cytolysis), by virally induced immunological mechanisms, or a combination of both, and this uncertainty is reflected in the inadequacy of treatment of these conditions.

Traditionally both conditions have been treated with steroids, but treatment has been prolonged, with frequent recurrences, and it is sometimes difficult to wean a patient completely off low dose maintenance topical steroids. Often despite treatment the disease spreads to parts of the eye not initially affected. ${ }^{1}$ Furthermore steroids, apart from being associated with local side effects, can lead to a continuation of the disease process by enhancing viral replication and suppressing local immune and defence mechanisms, and this could explain the chronicity of the disease.

The aim of this paper will be to present evidence that viral replication plays a major part in the disease process, and that early antiviral drug treatment of these two conditions has many advantages and is possible without the concomitant use of steroids.

Correspondence to J McGill, FRCS.

\section{Herpes simplex stromal disease}

Herpes simplex virus infection is common throughout the world and in the United Kingdom represents the commonest infectious cause of blindness, with $2.3 \%$ of all cases being notified to the central register. ${ }^{2}$ Stromal disease occurs in $25 \%$ of patients after their first herpes simplex epithelial ulcer, ${ }^{34}$ with $75 \%$ occurring within the first year. If topical steroids are used in the initial ulcerative attack, there is a higher incidence of stromal disease ${ }^{35}$ There are two sorts of stromal response, that underlying an active epithelial ulcer, and that occurring some time after the epithelial lesion has healed, or indeed occurring without a preceding epithelial lesion. In the latter case the typical stromal lesion of disciform keratitis is a centrally localised infiltration with oedema and swelling of the corneal stroma, folds in Descemet's membrane, and sometimes secondary glaucoma, uveitis, or occasionally an overlying dendritic ulcer. Alternatively the lesion may be eccentric or occupy the entire cornea. The exact classification, though, of the herpes simplex induced stromal diseases must await the determination of the exact and relative role of virus replication and immune mechanisms.

\section{Herpes zoster stromal disease}

Herpes zoster infections occur in $\mathbf{0 . 2} \%$ of the population, with the trigeminal nerve the most commonly involved. Of these cases ocular involvement occurs in 
Table 1 Herpes zoster keratouveitis: a retrospective analysis of 112 patients, of whom 82 had epithelial lesions, showing the incidence of stromal lesions and uveitis subsequently developing

\begin{tabular}{|c|c|c|c|c|c|c|}
\hline & \multicolumn{2}{|c|}{$\begin{array}{l}\text { Disciform } \\
\text { keratitis }\end{array}$} & \multicolumn{2}{|c|}{$\begin{array}{l}\text { Localised } \\
\text { infiltrate }\end{array}$} & \multicolumn{2}{|c|}{ Uveitis } \\
\hline & No. & $\%$ & No. & $\%$ & No. & $\%$ \\
\hline & 23 & $20 \cdot 5$ & 31 & 27.6 & 81 & $72 \cdot 3$ \\
\hline $\begin{array}{l}\text { With preceeding } \\
\text { epithelial lesion (82) }\end{array}$ & 18 & $78 \cdot 3$ & 24 & $77 \cdot 4$ & 77 & 95 \\
\hline $\begin{array}{l}\text { No preceeding } \\
\text { epithelial lesion }(0)\end{array}$ & 5 & $21 \cdot 7$ & 7 & $22 \cdot 6$ & 4 & 5 \\
\hline
\end{tabular}

over $50 \%$. In the acute phase $50-73 \%$ will develop epithelial involvement, either a punctate keratopathy or pseudodendritic formation. ${ }^{67}$ In a recent retrospective analysis of 112 patients $42(37.5 \%)$ developed stromal disease after previous epithelial involvement as opposed to only 12 patients $(10 \cdot 7 \%)$ developing stromal disease with no preceding epithelial involvement. In other words, if there had been previous epithelial involvement, over $50 \%$ (42 out of 82) developed stromal disease (Table 1).

In the same analysis it was found that anterior stromal nummular infiltrates or passages were geographically related to previous epithelial disease in $92 \%$ of patients, occurring soon after the onset of epithelial disease itself. Disciform keratitis occurred in $20 \%$ of patients, and characteristically after a delayed interval-after more than 21 days-78\% having had previous epithelial disease. Uveitis occurred in $72 \%$ of all patients, only $5 \%$ of whom had not had preceding epithelial disease. Late epithelial disease, including delayed mucous plaques associated with corneal anaesthesia and previous epithelial disease, and neuroparalytic and exposure keratitis, represents epithelial disturbance rather than active viral invasion, for no herpes zoster virus has been isolated from these lesions.

\section{Corneal response to viral infection}

When viral infection takes place, tear immunoproteins such as IgA and IgG act to neutralise the virus and prevent it colonising the epithelial cells. Once this has occurred, though, viral replication takes place within the cells, which are destroyed, an ulcer results, and free virus is released. Either virus penetrates the stroma, enters the keratocytes, replicates, and leads to cytolysis, which in itself leads to an acute inflammation, or soluble viral antigen permeates from the surface and becomes attached to the stromal keratocyte membranes, altering their membrane antigenicity and setting up an immune reaction. Finally, incomplete viral particles can enter the stroma, setting up an immune reaction. In herpes simplex stromal disease the local cellular or immune reaction is mainly $T$ cell mediated, with sensitised lymphocytes producing cytotoxicity by way of a local cell mediated hypersensitivity. Natural killer T cells, whose action is not dependent on previous sensitisation, may also play a part, for they have been shown in graft rejection to destroy donor endothelial cells. ${ }^{8}$ Thus the stromal response is due to soluble sensitised immunoprotein, such as IgG, acting together with a sensitised cell mediated system, with activation of complement. The HLA antigen system is expressed in the normal corneal stroma with both class I HLA antigens, the major histocompatability complex antigen acting as an effective agent for both cellular and humoral immune systems, and class II HLA systems present. ${ }^{9}$ After herpes simplex infection HLA class II (HLA D) antigens are expressed on stromal cells (Ward K A, et al., in preparation). Such abnormal expression of class II antigens is observed in a variety of autoimmune diseases and would explain how the HSV virus can initiate a cell mediated response.

Such humoral and cellular mediated responses would block viral replication, causing an abortive reaction, but as the virus has already entered the keratocyte its surface antigenicity would have been altered, so that the corneal defence mechanism would recognise it as 'non-self', producing a cell mediated response. It is a feature of both herpes simplex and zoster disciform keratitis that the disease process is chronic. If the reaction was simply due to a cell mediated hypersensitivity reaction, it would be expected to be self limiting, but with topical steroid treatment, either after or during withdrawal, rebound recurrences are frequent, suggesting continued antigenic stimulus. Nowadays, very few cases of herpes simplex stromal disease are left untreated with steroids, and much of the severity of these cases has been attributed to the advent of steroids, ${ }^{10}$ which lead to local immunosuppression but allow viral replication to proceed with continued antigenic stimulation.

But what is the evidence that viral replication plays a part in the stromal response? In herpes simplex keratitis, tear herpes simplex virus (HSV) specific secretory $\operatorname{IgA}(\operatorname{sIgA})$ has been found after acute epithelial disease, ${ }^{11}$ and there is a marked local production of virus specific IgG subclass in response to epithelial and stromal infection. ${ }^{9}$ Antibody in this subclass may be poorly neutralising, as it fails to fix complement and only weakly promotes an antibodydependent cell mediated cytotoxic reaction. Moreover IgG4 antibody production may result in an atopic reaction, as it combines,with mast cells and 
causes degranulation when cross-linked by antigens, and this would account for some of the stromal destruction and response seen in stromal disease.

It was Barrie Jones who with Alan Patterson ${ }^{12}$ showed that, if disciform keratitis was treated alone with steroids, a herpes simplex ulcer would appear on the epithelium in a high percentage of such cases. Herpes simplex particles have been demonstrated in the corneal stroma ${ }^{13-17}$ and HSV isolated from organ cultured corneal discs in patients with disciform keratitis. ${ }^{15} 18$ Herpes simplex viral particles have been seen in necrotising stromal keratitis. ${ }^{1319}$ Some workers have attributed disciform keratitis to a direct viral invasion of the endothelium on the basis of herpes simplex virus isolation from the aqueous, ${ }^{20}$ and herpes simplex viral has been cultured from the aqueous in cases of focal iritis and persistent endotheliitis with a secondary glaucoma. ${ }^{20}$ Incomplete virus, virions, or empty capsids have been found in the stroma of a patient with disciform keratitis, with HSV antigen localised either near herpes virions in keratocyte cell nuclei or in the stroma in areas of degenerating keratocytes ${ }^{16-18}$ and on keratocyte nuclear membranes. ${ }^{16}$

The sources of such virus include the stroma itself, the ocular adnexa and tears, and the trigeminal ganglion known to be colonised after infection ${ }^{21}$ reaching the stroma by way of the corneal branchesthe so-called back door approach ${ }^{22}$. Such continued antigenic stimulation would suggest initiation by residual virus or viral remnants. The clinical appearance of disciform keratitis can be produced in the rabbit eye by herpes antigen injection, ${ }^{2324}$ antigen being found on the stromal keratocytes with lymphocytes in close proximity, suggesting a cell mediated response. The direct injection of herpes virus into the rabbit stroma produces infiltrates, though its similarity to the clinical picture of disciform keratitis is uncertain, and such an animal model is probably more akin to the infiltrate beneath an ulcer in man. Antiviral treatment of these infiltrates with either triflurothymidine $^{25}$ or bromovinyldeoxyuridine ${ }^{26}$ improved the stromal response.

In rabbits different herpes simplex strains produce different responses. Strains producing a stromal response have an increased glycoprotein content compared with those producing only epithelial responses, ${ }^{27}$ and there is evidence that genetics plays a part, for the viral genome determines the extent of ocular herpes infection, its severity, its tendency towards recurrent disease, and the tissue response to steroids, independently of any host immunity or resistance. ${ }^{28}$ If the appropriate HSV strain is inoculated into the rabbit cornea, stromal involvement is seen beneath the ulcer, and a disciform keratitis lesion is seen after the seventh day. ${ }^{2829}$ But poly- morphonuclear cells are important in the development of the lesion, for if the rabbits are treated with serum acting against the polymorphonuclear cells the reaction is much less. ${ }^{30}$

In herpes zoster infection the exact mechanism and pathogenesis of the ocular signs is not known, partly because of the paucity of pathology of the stromal lesions and partly owing to the lack of a suitable animal model. Herpes zoster virus has been cultured from the acute epithelial lesions of both punctate keratopathy and pseudodendrites, ${ }^{31}$ from which multinuclear giant cells and intranuclear occlusion have been found ${ }^{32}$ and which are the most common manifestation of ocular involvement. A high proportion $(92 \%)$ of the anterior stromal deposits which resolve into nummular scars occur in areas underlying a previous punctate keratopathy or pseudodendritic ulcer ${ }^{6}$ (Table 1). These lesions could be due to direct viral invasion, or the diffusion of soluble viral antigen into the stroma, or damage to the terminal corneal nerves from virus travelling down the trigeminal branch. Similarly keratouveitis frequently occurs after epithelial involvement-in $95 \%$ of patients ${ }^{6}$ (Table 1). It is uncertain whether the ocular abnormalities are due to vasculitis causing ischaemia or chronic inflammation. Histological examination of early cases has shown that only the epithelium tends to be affected, with the deep corneal layers clear, but in chronically affected cases granulomatous reactions to Descemet's membrane have been seen ${ }^{33}$ and viral particles have been found in the endothelium ${ }^{3435}$ and retina. ${ }^{36}$ Disciform keratitis also occurs after epithelial disease but not in the same area, and, as lymphocytes are found in the affected region, it is thought to be due to a hypersensitivity reaction to viral antigen. ${ }^{6}$

Thus the available evidence points to direct viral involvement of the stromal lesions in both herpes simplex and zoster disease, either by setting up a cytotoxic reaction after cellular invasion, or by initiating immunological mechanisms which are responsible for the clinical signs that are so familiar in these cases. If it could be shown that those antiviral agents which enter the stroma in therapeutic concentrations do control the disease process, this would be evidence that viral replication at least plays a partan initiating role-in such disease processes.

\section{Clinical results}

TOPICAL ANTIVIRAL CHEMOTHERAPY

Herpes simplex disease

INTRODUCTION

Topically applied chemotherapeutic drugs have a definite role in the treatment of epithelial disease, 
Table 2 Outcome of comparative trial of topical acyclovir $(A C V)$ and adenine arabinoside (Ara A) on the stromal response beneath herpes simplex epithelial lesion. Treatment was five times a day until the signs resolved, then it was weaned off over two weeks

\begin{tabular}{lllll}
\hline & Number & Healed & $\begin{array}{l}\text { Days to } \\
\text { heal }\end{array}$ & $\begin{array}{l}\text { Steroids } \\
\text { required }\end{array}$ \\
\hline ACV & 20 & 20 & $12 \cdot 3$ & 0 \\
ARA-A & 17 & 12 & $8 \cdot 0$ & 5 \\
\hline
\end{tabular}

From McGill, Tormey, Walker. ${ }^{37}$

known to be due to viral replication and virally induced cell destruction, but do not affect either latency ${ }^{3-5}$ (recurrences) or the incidence of subsequent stromal disease. Idoxuridine, which is highly insoluble and does not penetrate into the corneal stroma, has no effect on stromal disease, but the question arises whether alternative antivirals that do penetrate have such an effect.

\section{CLINICAL}

Patients were divided up into those who had a stromal response beneath an active corneal ulcer, and those who had a typical lesion of herpes simplex disciform keratitis following on a previous attack of dendritic ulceration but with no concurrent epithelial disease present. In a double blind trial topical acyclovir and adenine arabinoside were compared in the treatment of the herpes simplex stromal response beneath the ulcer. Acyclovir was superior to Ara- $\mathrm{A}^{37}$ (Table 2).

In disciform keratitis acyclovir alone was of effect only in those patients who had never previously had topical steroids. Fourteen of 15 such patients responded satisfactorily, but if topical steroids had been used in a previous attack (with topical antivirals) then only one of 13 responded satisfactorily. The duration of treatment of acyclovir treated patients was shorter and rebound recurrences fewer than for those patients treated with a combination of acyclovir and steroids. In other words, once steroids were added to the regimen, all the familiar problems of steroid treatment, namely prolonged treatment therapy and frequent recurrences, were seen (Table 3 ). The degree of visual loss resulting from the residual stromal scarring was the same in the two groups, showing that withholding steroids did not lead to increased stromal scarring.

\section{CONCLUSION}

For those patients with their first attack of disciform keratitis and who have never been treated with steroids, topical antivirals that penetrate to the corneal stroma have in a comparatively short treatment course been successful in a high percentage of cases, without any significant sight impairing residual stromal scarring. The reason why prior steroid therapy makes the patient steroid dependent for subsequent attacks is unknown.

Adenine arabinoside is known not to penetrate the corneal stroma in therapeutic amounts. This explains why topical acyclovir was superior in treating herpes simplex induced infiltrative stromal disease beneath an ulcer. That topical acyclovir alone was able to control the stromal disease suggests that viral replication plays at least a part in the disease process. Collum and his colleagues ${ }^{38}$ found that, in a comparison of acyclovir with or without topical steroids in the treatment of disciform keratitis, $40 \%$ of those patients treated with acyclovir alone healed within 50 days, but it is uncertain how many had had steroids previously, so that these results may have been improved if these patients had been excluded. Similarly Sanitato et al. ${ }^{19}$ and Kaufman ${ }^{39}$ found that acyclovir alone had a beneficial effect in five of 12 patients with disciform keratitis, but it was not clear from their results how many of these patients had had prior attacks treated with steroids. Acyclovir has also been successfully used in the treatment of presumed herpetic iridoxcyclitis when given either topically (personal observation) or systemically. ${ }^{40}$

It is suggested that for the first attack of herpes simplex induced stromal disease acyclovir or trifluoro-

Table 3 Response of topical acyclovir (ACV) or triflurothymidine (F3T) on herpes simplex disciform keratitis in patients who either had never had topical steroids or had had a previous attack of stromal disease treated with steroids and antivirals

\begin{tabular}{|c|c|c|c|c|c|c|c|c|c|}
\hline & \multirow[t]{2}{*}{ No. } & \multirow[t]{2}{*}{ Healed } & \multirow{2}{*}{$\begin{array}{l}\text { Signs } \\
\text { resolved }\end{array}$} & \multirow{2}{*}{$\begin{array}{l}\text { Treatment } \\
\text { duration } \\
\text { (days) }\end{array}$} & \multirow[t]{2}{*}{ Recurrences } & \multirow{2}{*}{$\begin{array}{l}\text { Average } \\
\text { follow-up } \\
\text { (months) }\end{array}$} & \multicolumn{3}{|c|}{ Change in vision } \\
\hline & & & & & & & $\begin{array}{l}\text { Percent } \\
\text { same }\end{array}$ & $\begin{array}{l}\text { Loss I line } \\
\text { Snellen }\end{array}$ & $\begin{array}{l}\text { Loss }>1 \text { line } \\
\text { Snellen }\end{array}$ \\
\hline \multicolumn{10}{|l|}{$\begin{array}{l}\text { No prior } \\
\text { steroids }\end{array}$} \\
\hline ACV & 15 & 14 & $16 \cdot 5$ & $44 \cdot 3$ & 1 & $43 \cdot 2$ & $67 \%$ & $33 \%$ & \\
\hline F3T & 1 & 1 & 21 & 40 & 0 & 8 & & & \\
\hline \multicolumn{10}{|l|}{$\begin{array}{l}\text { Prior } \\
\text { steroids }\end{array}$} \\
\hline ACV & 13 & 1 & $16 \cdot 7$ & 112 & 7 & $48 \cdot 6$ & $53 \cdot 8 \%$ & $23 \cdot 1 \%$ & $23 \cdot 1 \%$ \\
\hline
\end{tabular}


thymidine five times a day for two weeks should be initiated. If after this time there is no regression of the clinical signs, topical steroids should be added and, once the signs have regressed, the patient cautiously and slowly weaned off. As viral resistance to acyclovir has been seen both experimentally and clinically, ${ }^{41}{ }^{42}$ administration of the drug should be limited to as short a treatment period as clinically necessary.

\section{HERPES ZOSTER INFECTION}

If a drug has an effect on the skin rash which is known to be due to direct viral invasion, then, if zoster keratouveitis in its many forms is due at least in part to viral invasion and virally induced tissue damage, it would be expected that that drug would control some of the corneal disease.

The earlier available antivirals had no effect on the acute stages of the rash, or the incidence of postherpetic neuralgia, when given either systemically as adenine arabinoside ${ }^{43}$ and cytosine arabinoside $e^{434}$ or topically as idoxuridine, which initially, when combined with dimethyl sulphoxide (DMSO) for skin penetration, was thought to be of benefit ${ }^{45}$ but later found to have no benefit over DMSO alone. ${ }^{46}$ Systemic steroids used to lessen postherpetic neuralgia resulting from viral induced tissue damage carried the risk of virol dissemination. ${ }^{47}$ Acyclovir has been shown in vitro to have antiviral activity against the varicella zoster virus ${ }^{48}$ and initial clinical trials suggested a beneficial clinical effect on the skin rash. ${ }^{49}$ Placebo controlled double blind trials of intravenous acyclovir have shown that acyclovir treated patients fared significantly better in terms of duration of new lesion formation and the time of loss of vesicles and the time to full crusting. ${ }^{50-52}$

Intravenous therapy is not an ideal mode of therapy for most patients, and so an oral form of the drug has been developed. In a multicentred controlled clinical trial oral acyclovir at $800 \mathrm{mg}$ five times daily for seven days has been found to be superior to placebo in significantly reducing the skin rash duration and associated pain (McKendrick et al., in press), whilst Cobo et al..$^{53}$ have shown that oral acyclovir at $600 \mathrm{mg}$ five times a day for 10 days, when compared with placebo in herpes zoster ophthalmicus, significantly reduced skin involvement and viral shedding, and ocular disease signs were lessened.

The question arises whether a drug effective against the skin rash is effective also against corneal disease.

\section{CLINICAL}

An open study of acyclovir ointment in acute herpes zoster keratouveitis showed that most patients had a quick resolution of their symptoms without any recurrence of the disease process. ${ }^{54}$ This was in sharp contrast to the common clinical finding that patients treated with topical steroids required a prolonged course and suffered frequent recurrences. For this reason a double blind trial was set up to compare topical steroid and acyclovir ophthalmic ointment in the treatment of acute herpes zoster keratouveitis ${ }^{55}$ (Table 4). The total treatment duration in the acyclovir treated group was considerably less than for the steroid treated group. In a short follow-up of less than one year, while 12 of the 19 steroid treated patients had a recurrence of their keratouveitis once treatment was either being tapered off or stopped, none of the acyclovir treated patients had a recurrence. Corneal epithelial disease resolved signifcantly faster than in the acyclovir group, but there was no significant difference in the resolution of stromal disease, uveitis, or scleritis in the two groups.

In an attempt to gain a broader impression of the usefulness of acyclovir in acute herpes zoster keratouveitis, a retrospective analysis was carried out of all patients with this disease presenting at the Southampton Eye Hospital over a two-year period and treated by a number of doctors. ${ }^{56}$ Retrospective analyses are not ideal, and exact differences between groups for particular signs resolving may not be clear, but, when the clinical outcome of these patients treated with either topical acyclovir or steroids or a combination of both was reviewed, a definite pattern emerged. Topical acyclovir alone controlled the disease process in 51 out of 56 patients. Those treated with acyclovir fared significantly better, with a quicker resolution of their keratouveitis, as there were no recurrences of the disease process in the first year after treatment had been stopped compared with a $50 \%$ incidence of those treated with topical steroids, many of whom are still on treatment, so that the total treatment duration of the steroid treated patients was much longer. ${ }^{56}$ With a longer follow-up two out of 56 of the patients treated with acyclovir had a recurrence of their keratouveitis, one of whom had had topical steroids for his lid involvement. ${ }^{56}$ In an up-to-date retrospective analysis of all patients treated with topical acyclovir the time taken for resolution was the same for the different types of stromal disease (Table 5). But acyclovir, when combined with steroids, showed no benefit compared with the steroids alone. In other words the addition of steroids produces all the problems of prolonged treatment and frequent recurrences.

These trials, however, may have merely been showing the deleterious effect of steroids and not a beneficial one of acyclovir, as it was ethically impossible to use placebo controls in patients who had established keratouveitis causing a painful inflamed 
Table 4 Outcome of treatment with either topical acylovir or topical steroids (Betnesol) five times a day on acute herpes zoster ocular involvement

\begin{tabular}{|c|c|c|c|c|c|}
\hline Group & Number & Number healed & $\begin{array}{l}\text { Initial treatment } \\
\text { duration (median days) }\end{array}$ & $\begin{array}{l}\text { Number disease } \\
\text { reappeared }\end{array}$ & $\begin{array}{l}\text { Total treatment } \\
\text { duration (median } \\
\text { days) }\end{array}$ \\
\hline $\begin{array}{l}\text { Acyclovir } \\
\text { Steroids }\end{array}$ & $\begin{array}{l}17 \\
19\end{array}$ & $\begin{array}{l}16 \\
18\end{array}$ & $\begin{array}{l}75 \\
68\end{array}$ & $\begin{array}{c}0 \\
12 *(63 \%)\end{array}$ & $\begin{array}{c}75 \text { (range } 17-144 \text { ) } \\
2804 \text { (range } 34-440)\end{array}$ \\
\hline
\end{tabular}

${ }^{*} \mathrm{p}<0.001$ (Fisher's exact test, 2-tailed).

$t \mathrm{p}=0.002$ (Mann-Whitney U test, 2-tailed).

From McGill and Chapman. ${ }^{5 s}$

Table 5 Herpes zoster keratouveitis: retrospective analysis of patients treated with topical acyclovir compared with those treated with steroids or a combination of both

\begin{tabular}{|c|c|c|c|c|c|c|c|c|c|}
\hline \multirow[t]{2}{*}{ Number } & \multicolumn{3}{|c|}{ Acyclovir (112) } & \multicolumn{3}{|c|}{ Steroids (74) } & \multicolumn{3}{|c|}{ Acyclovir + steroids (14) } \\
\hline & No. & Healed & Days to heal & No. & Healed & Days to heal & No. & Healed & Days to heal \\
\hline Epithelial & 82 & 82 & 6.06 & 20 & 20 & 10 & 4 & 4 & 12 \\
\hline Disciform keratitis & 25 & 25 & $16 \cdot 6$ & 16 & 16 & 38 & 2 & 2 & 48 \\
\hline Nummular keratitis & 32 & 29 & $15 \cdot 4$ & 19 & 19 & $27 \cdot 7$ & 3 & 3 & 61 \\
\hline Uveitis & 89 & 83 & $21 \cdot 7$ & 56 & 56 & 53 & 7 & 7 & 92 \\
\hline Average treatment duration & & & $62 \cdot 3$ & & & 200 & & & 197 \\
\hline Total recurrence rate & & & $2 \%$ & & & $50 \%$ & & & $57 \%$ \\
\hline
\end{tabular}

eye. If in very early cases it could be shown that acyclovir stopped the disease from developing (compared with placebo), this would support the concept of an active role for this drug. In an attempt to settle this problem a prophylactic double blind placebo controlled trial was carried out on patients whose skin rash had resolved and whose eye showed minimal involvement of conjunctival injection or

Table 6 Outcome of a randomised double blind trial of topical acyclovir compared with placebo in the treatment of herpes zoster keratouveitis. The ocular signs at the onset were minimal, either being conjunctival injection or an early punctate keratopathy (early corneal involvement). The ocular disease process was halted in the acyclovir treated patients but progressed in 8-10 placebo treated patients, showing that acyclovir actively protects the eye from damage if treatment is started early enough

\begin{tabular}{llll}
\hline Treatment & No. of patients & Halted & Progressed \\
\hline Acyclovir & 10 & 10 & 0 \\
Placebo & 10 & 2 & 8 \\
\hline
\end{tabular}

Table 7 Herpes zoster keratouveitis: In nine patients, showing the cause of failure to respond to topical acyclovir (several patients had more than one sign)

\begin{tabular}{lr}
\hline & No. \\
\hline Scleritis & 3 \\
Nummular infiltrate (2 had marginal infiltrate) & 3 \\
Uveitis & 6 \\
\hline
\end{tabular}

simply an acute punctate keratopathy (Table 6). Of the 20 patients treated 10 had topical acyclovir, 10 topical placebo. All patients treated with topical acyclovir fared well, with a quick resolution and no disease progression or stromal involvement. Eight out of 10 of the patients treated with placebo had a progression of their disease, with stromal involvement, and acyclovir had to be added before the disease resolved.

In reviewing all 112 acyclovir treated patients, all but one of whom presented within three weeks of the onset of their disease, we noted nine not responding to acyclovir alone (Table 7). It is suggested that if scleritis or uveitis persists, especially if synechiae have formed, steroids should not be withheld.

\section{CONCLUSION}

Most cases of herpes zoster stromal disease follow epithelial involvement, with nummular opacities occurring sooner than disciform keratitis, suggesting a different mechanism. As epithelial lesions are known to be associated with herpes zoster virus, and as stromal disease can be prevented if epithelial disease is treated with antiviral chemotherapy, and established stromal lesions can be similarly treated, this evidence suggests that viral replication has a major role in the development of these lesions.

Previously topical steroids were the only available treatment of herpes zoster keratouveitis, and they had to be continued for up to 18 months or more, with much disease progression, ocular damage and visual loss. With topical acyclovir there is a shorter treat- 
ment duration, less recurrence, and less disease spread, but it must be emphasised that this comparison may be showing up the deleterious effects of steroids on viral induced stromal disease, and further prophylactic oral and topically based clinical trials are required to determine the relative effective role of antivirals in this condition, particularly as the exact mechanism of the production of the different signs is not yet known. For instance, nummular opacities, which develop earlier than disciform keratitis and in direct relation to epithelial ulcers, may be due to a different immune mechanism than the cell mediated delayed immune mechanism of disciform keratitis.

\section{General conclusion}

In both herpes simplex and zoster ocular infections, stromal lesions usually follow after epithelial disease. The exact mechanism of these disease processes is not yet fully understood, partly owing to the lack of any suitable animal model. But the fact that stromal disease occurs after epithelial disease, and the effect shown here of antivirals on stromal disease, suggest that viral replication has a major role in the production of the stromal lesions. Antiviral treatment alone without the use of steroids offers considerable advantages, but the exact role of antivirals in the disease process must await further laboratory work and coded clinical trials. Prophylactic placebo controlled trials are required to determine whether topical antivirals are superior to placebo in all aspects of stromal disease, and whether any significant vision threatening stromal scarring results from the withholding of steroids.

Grateful thanks to my colleagues M J Absolon, FRCS, I H Chisholm, FRCS, A R Elkington, FRCS, and C B Walker, FRCS, for referring patients to me and for allowing me. to review the patients' case notes, and to Wendy Gilbert for typing the manuscript.

\section{References}

1 McGill JI. Potential treatments for herpes zoster infection In: Kono R, Nakajima N, eds. Herpes viruses and virus chemotherapy. Amsterdam: Elsevier, 1985: 113-8.

2 Sorsby A. Reports on public health and medical subjects. No. 128. London: HMSO, 1972.

3 McGill JI, Williams HP, McKinnon JR, Wilson ADH, Jones BR. Reassessment of idoxuridine therapy of herpetic keratitis. Trans Ophthalmol Soc UK 1974; 94: 542-51.

4 Wilhelmus KR, Coster DJ, Donovan HC, Falcon MG, Jones BR. Prognostic indicators of herpetic keratitis-analysis of a five-year observation period after corneal ulceration. Arch Ophthalmol 1981; 99: 1578-82.

5 Wilhelmus KR, Coster DJ, Falcon MJ, Jones BR. Longitudinal analysis of ulcerative herpetic keratitis. In: Sundmacher $R$, ed. Herpetische Augenerkrankungen. Munich: Bergmann, 1980: $375-8$.

6 Leisegang TJ. Corneal complications from herpes zoster ophthalmicus. Ophthalmology (Rochester) 1985; 92: 316-24.
7 Marsh R. Herpes zoster keratitis. Trans Ophthalmol Soc UK 1973; 93: 181-92.

8 Opremcatz EM, Whisler RC, Dongel ME. Natural killer cells against human cell endothelium. Am JOphthalmol 1985;99: 524-9.

9 Treseler PA, Foulks GN, Sanfilippo F. The expression of HLA antigens by cells in the human cornea. Am J Ophthalmol 1984; 98: 763-22.

10 Thygeson P, Kimura SJ. Deep forms of herpetic keratitis. Am J Ophthalmol 1957; 43: 109-13.

11 Fox PD, Khaw PT, McBride BW, McGill J, Ward KA. Tear and serum antibody levels in ocular herpetic infection: diagnostic precision of secretory IgA. BrJ Ophthalmol in press.

12 Patterson A, Jones BR. Management of ocular herpes. Tran Ophthalmol Soc UK 1967; 87: 59-84.

13 Dawson C, Togui B, Moore TE Jr. Structural changes in chronic herpetic keratitis, studied by light and electron microscopy. Arch Ophthalmol 1968; 79: 740-7.

14 Collin HB, Abelson MB. Herpes simplex virus in human cornea: retrocorneal retinous membrane and vitreous. Arch Ophthalmol 1976; 94: 1726-9.

15 Jones SR. Falcon MG. Williams HP. Coster DJ. Objectives in therapy of herpetic eye disease. Trans Ophthalmol Soc UK 1977; 97: 305-13.

16 Meyers-Elliott RH, Pettit TH, Maxwell A. Viral antigens in the immune ring of herpes simplex stromal keratitis. Arch Ophthalmol 1980; 98: 897-904.

17 Shimeld C, Tullo AB, Easty DL, Thomsitt J. Isolation of herpes simplex cirus from cornea in chronic stromal keratitis. $\mathrm{Br} J$ Ophthalmol 1982; 66: 653-47.

18 Tullo AB, Easty DG, Shimeld C, Stirling P, Darrille M. Isolation of herpes simplex virus from corneal dises in chronic stromal keratitis. In: Maugdal PE, Missotten, L, eds. Herpetic disease. Doc Ophthalmol 1984; 44: 57-63.

19 Sanitato JJ, Asbel P, Warwell ED, Kissling GE, Kaufman HE. Acyclovir in the treatment of herpes stromal disease. Am J Ophthalmol 1984; 98: 537-47.

20 Sundmacher R. A clinico-virologic classification of herpetic anterior segment disease with special reference to intraocular herpes. In: Herpetische Augenerkrankungen, Sundmacher R. Munich: Bergmann, 1981: 203-7.

21 Baringer JR, Swoveland P. Recovery of herpes simplex virus from human trigeminal ganglions. New Engl J Med 1973; 288: 648-50.

22 Tullo AB, Shimeld C, Blyth WH, Hill TJ, Easty DL. Latent infection following ocular herpes simplex in non-immune and immune mice. J Gen Virol 1982; 63: 95-100.

23 Swyers JS, Lausch RH, Kaufman HE. Corneal hypersensitivity to herpes simplex. Br J Ophthalmol 1967; 51: 843-6.

24 Metcalf JF, Kaufman HE. 1976. Herpetic stromal keratitis: evidence for cell mediated immunopathogenesis. Am J Ophthalmol 1976; 82: 827-34.

25 McNeil J, Kaufman HE. Local antivirals in a herpes simplex stromal keratitis model. Am J Ophthalmol 1979; 97: 727-9.

26 Maudgal PC, De Clercg E, Descamps J, Missotten L, Wijnhoven J. Experimental stromal herpes simplex keratitis. Arch Ophthalmol 1982; 100: 653-6.

27 Certifarlo-Fitzgerald YM, Fenger T, Kaufman HE. Virus proteins in herpetic keratitis. Exp Eye Res 1982; 35: 425-41.

28 Kaufman HE, Varnell ED, Centifanto BS, Kissling GE. Effect of the herpes simplex virus genome on the response of infection to corticosteroids. Am J Ophthalmol 1985; 100: 114-8.

29 Meyers-Elliott RH, Clitjian PA. Induction of cell mediated immunity in herpes simplex virus keratitis, kinetics of lymphocyte-transformation and the effect of anti-viral antibody. Invest Ophthalmol Vis Sci 1980; 19: 920-9.

30 Meyers-Elliott RH, Clitjian PA. Immunopathogenesis of corneal inflammation in herpes simplex virus stromal keratitis: role of polymorphonuclear leucocytes. Invest Ophthalmol Vis Sci 1980; 20: 86-99. 
31 Langston DP. Varicella-zoster ophthalmicus. Int Ophthalmol Clin 1975; 15: 171-85.

32 Marsh RJ, Fraunfelder F, McGill JI. Herpetic corneal epithelial disease. Arch Ophthalmol 1976; 94: 1899-902.

33 Hedges III TR, Albert DM. The progression of the ocular abnormalities of herpes zoster. J Am Acad Ophthalmol 1982; 89: 165-77.

34 Maudgal PC, Missotten L, De Clercq E, Descamps J. Varicellazoster virus in the human corneal endothelium. Bull Soc Belge Ophtalmol 1980; 190: 71-86.

35 Witmer R, Iwanto T. Electron microscrope observation of herpes-like particles in the iris. Arch Ophthalmol 1968; 79: 331-7.

36 Schwartz JN, Cashwell F, Hawkins HK, Klintworth GK. Necrotizing retinopathy with herpes zoster ophthalmicus: a light and electron microscopical study. Arch Pathol Lab Med 1976; 100: 386-91.

37 McGill JI, Tormey P, Walker CB. Comparative trial of acyclovir and adenine arabinoside in the treatment of herpes simplex stromal disease. $\mathrm{Br} J$ Ophthalmol 1981; 65: 610-3.

38 Collum LMT, Logan P, Ravenscroft P. Acyclovir (Zovirax) in herpetic disciform keratitis. BrJ Ophthalmol 1983; 67: 125-8.

39 Kaufman HE. Update on antiviral agents: an overview on ocular herpes viruses and viral chemotherapy. In: Kono R, Nakajima $\mathrm{N}$, eds. Herpes viruses and virus chemotherapy. Amsterdam: Excerpta Medica, 1985: 91-4.

40 Wilhelmus KR, Falcon MG, Jones BL. Herpetic iridocyclitis. Int Ophthalmol 1982; 4: 143-50.

41 Burns WH, Sarol R, Santos PW, Laskin LL. Isolation and characterization of resistant herpes simplex virus after acyclovir therapy. Lancet 1982; i: 421.

42 Balfour HH. Resistance of herpes simplex to acyclovir. Ann Intern Med 1983; 98: 404.

43 Marsh RJ, Laird R, Atkinson A, Steel A McD, Jones BR. A controlled trial of intravenous therapy with adenine arabinoside (Ara-A) in ophthalmic zoster. In: Sundmacher $\mathbf{R}$, ed. Herpetische Augenerkrankungen. Munich: Bergmann, 1981: 449-54.

44 Davis CM, Van Dersarl JV, Coltman CA. Failure of cytarabine in varicella-zoster infections. JAMA 1973; 224: 122-3.
45 Juel-Jensen BE, MacCallum FO, MacKenzie AMR, Pike MC. Treatment of zoster with idoxuridine in dimethyl sulphoxide. Results of two double-blind controlled trials. $\mathrm{Br}$ Med J 1970; iv: 776-80.

46 Wildenhoff KE, Ipsen J, Esmann V, Ingemann-Jensen J, Poulsen JH. Treatment of herpes zoster with idoxuridine ointment, including a multivariate analysis of symptoms and signs. Scand J Infect Dis 1979; 11: 1-9.

47 Elliott FA. Treatment of herpes zoster with high doses of prednisolone. Lancet 1964; ii: 610-1.

48 Fyfe JA, Biron KK. Phosphorylation of acyclovir by a thymidine kinase induced by varicella-zoster virus. Proceedings of the 11th International Congress of Chemotherapy and 19th Interscience Conference on Antimicrobial Agents and Chemotherapy. Boston, $1980 ; 2: 1378-9$.

49 McGill JI, James D, Hiscott P, Worstman T, Larkin M. The use of acyclovir in the treatment of herpes zoster ocular infections. In: Sundmacher R, ed. Herpetische Augenerkrankungen. Munich: Bergmann, 1981: 461-4.

50 Peterslund NA, Seyer-Hansen K, Ipsen J, Esman V, Schonheyder H, Juhl H. Acyclovir in herpes zoster. Lancet 1981; ii: $827-30$.

51 Bean B, Braun C, Balfour HH. Acyclovir therapy for acute herpes zoster. Lancet 1982; ii: 118-21.

52 McGill JI, McDonald DR, Fall C, McKendrick GDW, Copplestone A. Intravenous acyclovir in acute herpes zoster infection. $J$ Infect 1983; 6: 157-61.

53 Cobo LM, Foulks GN, Leisegang TJ, et al. Oral acyclovir in the therapy of herpes zoster ophthalmicus-an interim report. Ophthalmology (Rochester) 1985; 92: 1574-83.

$54 \mathrm{McGill}$ JI. Topical acyclovir in herpes zoster ocular involvement. Br J Ophthalmol 1981; 65: 542-5.

55 McGill J, Chapman C. A comparison of topical acyclovir with steroids in the treatment of herpes zoster keratouveitis. $\mathrm{Br} J$ Ophthalmol 1983; 67: 746-50.

56 McGill JI. Herpes zoster treatment in herpetic eye diseases. In: Maudgal PC, Missotten L, eds. Herpetic Disease. Doc Ophthalmol 1985; 44: 413-9. 